\title{
Overexpression of short heterodimer partner recovers impaired glucose-stimulated insulin secretion of pancreatic $\beta$-cells overexpressing UCP2
}

\author{
Y-H Suh*, S-Y Kim*, H-Y Lee, B C Jang, J H Bae², J-N Sohn², \\ J-H Bae, S-I Suh, J-W Park, K-U Lee ${ }^{1}$ and D-K Song \\ Department of Physiology and Chronic Disease Research Center, Keimyung University School of Medicine, 194 Dongsan-Dong, Jung-Gu, Daegu, 700-712, \\ South Korea \\ ${ }^{1}$ Department of Internal Medicine, University of Ulsan College of Medicine, Seoul, 138-736, South Korea \\ ${ }^{2}$ Department of Food Science and Nutrition, University of Ulsan College of Medicine, Seoul, 138-736, South Korea \\ (Requests for offprints should be addressed to D-K Song; Email: dksong@kmu.ac.kr) \\ *(Y-H Suh and S-Y Kim contributed equally to this work)
}

\begin{abstract}
The short heterodimer partner (SHP) (NR0B2) is an orphan nuclear receptor whose function in pancreatic $\beta$-cells is unclear. Mitochondrial uncoupling protein (UCP2) in $\beta$-cells is upregulated in obesity-related diabetes, causing impaired glucose-stimulated insulin secretion (GSIS). We investigated whether SHP plays a role in UCP2-induced GSIS impairment. We overexpressed SHP in normal islet cells and in islet cells overexpressing UCP2 by an adenovirus-mediated infection technique. We found that SHP overexpression enhanced GSIS in normal islets, and restored GSIS in UCP2-overexpressing islets. SHP overexpression increased the glucose sensitivity of ATP-sensitive $\mathrm{K}^{+}\left(\mathrm{K}_{\mathrm{ATP}}\right)$ channels and enhanced the ATP/ADP ratio. A peroxisome proliferator-activated receptor gamma (PPAR $\gamma$ ) antagonist, GW9662, did not
\end{abstract}

block the SHP effect on GSIS. SHP overexpression also corrected the impaired sensitivity of UCP2overexpressing $\beta$-cells to methylpyruvate, another energy fuel that bypasses glycolysis and directly enters the Krebs cycle. $\mathrm{K}_{\mathrm{ATP}}$ channel inhibition mediated by dihydroxyacetone, which gives reducing equivalents directly to complex II of the electron transport system, was similar in Ad-Null-, Ad-UCP2- and Ad-UCP2+Ad-SHP-infected cells. The mitochondrial metabolic inhibitor sodium azide totally blocked the effect of SHP overexpression on GSIS. These results suggest that SHP positively regulates GSIS in $\beta$-cells and restores glucose sensitivity in UCP2overexpressing $\beta$-cells by enhancing mitochondrial glucose metabolism, independent of PPAR $\gamma$ activation.

Journal of Endocrinology (2004) 183, 133-144

\section{Introduction}

Type 2 diabetes is characterized by impaired insulin secretion by pancreatic $\beta$-cells in response to glucose, and by insulin resistance in tissues usually sensitive to insulin, such as liver, muscle and adipose tissues (DeFronzo 1988). Some type 2 diabetes is associated with mutations in diabetes-related genes (Schwanstecher et al. 2002). Maturity-onset diabetes in young adults (MODY) with impaired glucose-stimulated insulin secretion (GSIS) features a functional defect in at least one gene of the nuclear receptor superfamily (Shih et al. 2001).

Mutation in the short heterodimer partner (SHP) (NR0B2), which is an orphan nuclear receptor (Seol et al. 1996, Lee et al. 1998, Nishizawa et al. 2002), is commonly observed in type 2 diabetic patients (Mitchell et al. 2003). Although SHP can inhibit transcriptional activation activi- ties of many nuclear receptors by acting as a repressor (Seol et al. 1996, 1997, 1998, Johansson et al. 1999, Goodwin et al. 2000, Lee et al. 2000, Nishigori et al. 2001), it is also known to increase the transcriptional activation activity of the peroxisome proliferator-activated receptor $\gamma(\operatorname{PPAR} \gamma)$ (Nishizawa et al. 2002). SHP binds the promoter of the $P P A R \gamma$ gene at a SHP-binding site (Nishizawa et al. 2002). PPAR $\gamma$ activation often antagonizes diabetic development (Day 1999). In pancreatic $\beta$-cells, PPAR $\gamma$ agonists ameliorate GSIS (Yang et al. 2001) and prevent $\beta$-cells from undergoing apoptosis (Shimabukuro et al. 1997). Individuals who have early-onset type-2 diabetes due to a loss-of-function mutation in the $P P A R \gamma$ gene (Barroso et al. 1999) have been treated with PPAR $\gamma$ ligands (Day 1999). From these observations, it is suggested that SHP may be involved in the glucosecontrolling functions of insulin-secreting and/or insulin- 
sensitive tissues (Nishigori et al. 2001, Nishizawa et al. 2002). Despite these findings, however, there have been few studies aimed at defining the molecular role of SHP in this process.

A chronic fatty diet causes PPAR $\gamma$ upregulation in $\beta$-cells, associated with an increase in mitochondrial uncoupling protein 2 (UCP2) expression and a decrease in GSIS (Shimabukuro et al. 1997, Chan et al. 1999, 2001, Patane et al. 2002). These findings suggest a relationship between nuclear receptors and mitochondrial metabolic proteins in $\beta$-cell insulin secretory pathways. UCP2 is a proton $\left(\mathrm{H}^{+}\right)$carrier protein in the mitochondrial inner membrane that facilitates a proton leak across the membrane. UCP2-induced proton leakiness causes hypopolarization of the mitochondrial transmembrane potential $(\Delta \Psi \mathrm{m})$ and a sequential decrease in mitochondrial $\mathrm{Ca}^{2+}$ influx (Chan et al. 2001). Since intramitochondrial $\mathrm{Ca}^{2+}$ $\left(\left[\mathrm{Ca}^{2+}\right]_{\mathrm{m}}\right)$ regulates the activities of several dehydrogenases coupled to the Krebs cycle (McCormack et al. 1990, Rutter et al. 1996), a UCP2-induced $\left[\mathrm{Ca}^{2+}\right]_{\mathrm{m}}$ decrease may attenuate glucose metabolism in the mitochondria. UCP2 expression is often inversely correlated with the level of reactive oxygen species (ROS) (Skulachev 1998). Although high UCP2 expression can alleviate the cellular load of ROS during energy metabolism (Echtay et al. 2002), exaggerated UCP2 expression may cause GSIS impairment in $\beta$-cells (Chan et al. 1999, Zhang et al. 2001), which may eventually cause lower postprandial insulin levels in blood. Investigating the role of SHP in UCP2-induced impairment of mitochondrial metabolic function may ultimately reveal new antidiabetic targets.

The present study investigated the role of SHP in normal and UCP2-overexpressing diabetic $\beta$-cells using an adenoviral UCP2 infection system. We found that SHP enhanced GSIS in normal and UCP2-overexpressing $\beta$-cells, probably not via $\operatorname{PPAR} \gamma$ activation but through potentiating glucose metabolism in the mitochondria.

\section{Materials and Methods}

\section{Materials}

Fura-2 acetoxymethyl (Fura-2/AM) ester was obtained from Molecular Probes (Eugene, OR, USA). GW9662 was purchased from Alexis (Lausen, Switzerland). Bovine serum albumin (BSA) and fetal bovine serum (FBS) were purchased from Gibco Invitrogen (Carlsbad, CA, USA) and Hyclone (Logan, UT, USA) respectively. Rat insulin assay kits were purchased from Linco Research (St Charles, MO, USA). All other chemicals were obtained from Sigma.

\section{Preparation of islets and single $\beta$-cells}

Islets of Langerhans were isolated from the pancreata of male Sprague-Dawley rats, each weighing 200-250 g, by a collagenase digestion technique. Briefly, the animals were first anesthetized with Nembutal, and then humanely killed by exsanguination. All procedures were approved by the Institutional Animal Care and Use Committee at the Dongsan Medical Institute for Life Sciences in Daegu, South Korea. Collagenase (type V; Sigma) was dissolved to a concentration of $1 \mathrm{mg} / \mathrm{ml}$ in Hanks' balanced salt solution (HBSS) and transfused via the common bile duct into the pancreatic ducts. The dissected pancreas was then incubated for $15 \mathrm{~min}$ at $37^{\circ} \mathrm{C}$ in a shaking water bath. Islets were picked up on a stereoscope $(\times 15)$ and placed into Krebs-Ringer bicarbonate (KRB) buffer containing $10 \% \mathrm{BSA}$, penicillin $(100 \mathrm{U} / \mathrm{ml})$ and streptomycin $(0 \cdot 1 \mathrm{mg} / \mathrm{ml})$. To obtain single $\beta$-cells, islets were triturated with a fire-polished Pasteur pipette and a $1 \mathrm{ml}$ syringe, employing increasingly smaller needle diameters $(20-26$ gauges). Islets or single islet cells were incubated in RPMI-1640 media with $5 \mathrm{mM}$ glucose and $10 \%$ FBS in a humidified atmosphere of $5 \% \mathrm{CO}_{2}$ in air at $37^{\circ} \mathrm{C}$.

\section{Culture of insulin-secreting INS-1 $\beta$-cells}

INS-1 $\beta$-cells were routinely grown in monolayer cultures, as previously described (Asfari et al. 1992), in RPMI media containing $11.1 \mathrm{mM}$ glucose supplemented with $10 \mathrm{mM}$ HEPES, $2 \mathrm{mM}$ glutamine, $1 \mathrm{mM}$ sodium pyruvate, $50 \mu \mathrm{M} \beta$-mercaptoethanol and the antibiotics in the same incubator where $\beta$-cells were cultured. All studies were performed on INS-1 passages between 20 and 30 in appropriate test protocols.

\section{Recombinant adenovirus preparation and transfection}

A full-length human UCP2 (hUCP2/pBS) and SHP (hSHP/pCDNA3) were subcloned into the HindIII/ BamHI site of the pAd-YC2 shuttle vector (Choi et al. 2003). UCP2/pAd-YC2, SHP/pAd-YC2 and a rescue vector pJM17 (Graham \& van der Eb 1973) were cotransfected into human embryonic kidney 293 (HEK-293) cells with Tfx-20 (Promega, Madison, WI, USA), according to the manufacturer's protocol. After 12 days, recombinants were identified by PCR. The recombinants were amplified in HEK-293 cells and purified in a cesium chloride density gradient. The control adenovirus, AdNull, was made and identified by the same method. INS-1 or islet cells were infected with adenoviruses expressing Ad-Null (multiplicity of infection $[\mathrm{MOI}]=100$ ), Ad-SHP (50+Ad-Null 50), Ad-UCP2 (50+Ad-Null 50) or AdUCP2+Ad-SHP $(50+50)$. The adenovirus titer was $3.5 \times 10^{9}$ plaque-forming units (PFU), and one islet was assumed to have $10^{3} \beta$-cells (Chan et al. 2001). Virustreated dishes were incubated for $2 \mathrm{~h}$ at $37^{\circ} \mathrm{C}$, and then washed with RPMI media with low glucose. INS-1 and islet cells were maintained for $48 \mathrm{~h}$ after infection, after which time experiments were performed. 
Recordings of single ATP-sensitive potassium $\left(K_{A T P}\right)$ channel activity

The cell-attached configuration of the conventional patchclamp technique (Hamill et al. 1981) was used. Patch pipettes had a resistance of 3-5 M $\Omega$. The single-channel currents were recorded by an Axopatch 200B patch-clamp amplifier (Axon Instruments, Forster, CA, USA), passed onto an A/D converter (Digidata 1312; Axon Instruments) and later analyzed with Pclamp 8.2 software (Axon Instruments). Data were filtered at $1 \mathrm{KHz}$ and sampled at $5 \mathrm{KHz}$. They were further filtered at $20 \mathrm{~Hz}$ for the presentation of Figures. The channel activity was compared by the channel open probability $\left(\mathrm{P}_{\mathrm{o}}\right)$ calculated from the following formula,

$$
P_{\mathrm{o}}=\left(\sum_{j=1}^{N} t_{j}^{*} j\right) /\left(T_{d}^{*} N\right)
$$

where $\mathrm{t}_{j}$ is the time spent at current levels corresponding to $j=0,1,2, \ldots N$ channels in the open state; $T_{d}$ is the duration of the recording; and $N$ is the number of channels active in the patch. The number of channels in a patch was estimated by dividing the maximum current observed in the control solution by the mean unitary current amplitude. The relative channel activity in the presence of insulin secretagogues was described as $\mathrm{P}_{\mathrm{o}} / \mathrm{P}_{\mathrm{oc}}$, where $\mathrm{P}_{\mathrm{oc}}$ is the $\mathrm{P}_{\mathrm{o}}$ recorded during $30 \mathrm{~s}$ just before the administration of the drugs. During experiments, single islet cells on a cover glass $(10 \mathrm{~mm} \times 2 \mathrm{~mm})$ were bathed in a solution composed of (in mM) $137 \mathrm{NaCl}, 5 \cdot 6 \mathrm{KCl}, 1 \cdot 2 \mathrm{MgCl}_{2}, 2 \cdot 6$ $\mathrm{CaCl}_{2}$ and 10 HEPES, adjusted to $\mathrm{pH} 7 \cdot 4$ with $\mathrm{NaOH}$. The pipette solution contained (in $\mathrm{mM}$ ) $140 \mathrm{KCl}, 1 \cdot 2$ $\mathrm{MgCl}_{2}, 2 \cdot 6 \mathrm{CaCl}_{2}$ and $10 \mathrm{HEPES}$, adjusted to $\mathrm{pH} 7 \cdot 4$ with $\mathrm{KOH}$. The experiments were done at room temperature $\left(20-22^{\circ} \mathrm{C}\right)$.

\section{Measurement of insulin secretion from islets}

Insulin secretion from islets was measured by radioimmunoassay (RIA) using the batch incubation method. The islets were preincubated for $1 \mathrm{~h}$ at $37^{\circ} \mathrm{C}$ in a modified KRB buffer with $0 \cdot 1 \%$ BSA and no glucose. Ten islets were then placed into each well of a 48 -well plate containing an insulin secretagogue at the concentrations indicated. After incubation for $1 \mathrm{~h}$ at $37^{\circ} \mathrm{C}$, an aliquot was taken from each well and centrifuged $(700 \mathrm{~g}, 5 \mathrm{~min})$, and the supernatant $(200 \mu \mathrm{l})$ was carefully collected and stored $\left(-20{ }^{\circ} \mathrm{C}\right)$ for later analysis.

\section{Changes in cytosolic free- $\mathrm{Ca}^{2+}$ concentration $\left(\left[\mathrm{Ca}^{2+}\right] \mathrm{d}\right.$ in islet cells}

Microfluorescent imaging of $\left[\mathrm{Ca}^{2+}\right]_{c}$ was performed on single islet cells loaded with the calcium indicator dye Fura-2/AM. Some of the procedures used in $\mathrm{Ca}^{2+}$ imaging in this experiment have been previously described (Bae et al. 2003). Fura-2/AM ester $(3 \mu \mathrm{M})$ was added to islet cells, which were cultured on a cover slip ( $25 \mathrm{~mm}$ in diameter), and bathed in physiological saline solution (PSS) at room temperature for $30 \mathrm{~min}$, followed by a $30-\mathrm{min}$ wash in dye-free PSS to allow esterase conversion to free Fura-2. A cover slip was placed on the stage of an inverted microscope, and imaging was performed with an InCa dual-wavelength system (Intracellular Imaging, Cincinnati, OH, USA). $\left[\mathrm{Ca}^{2+}\right]_{\mathrm{c}}$ was calculated as the relationship between the ratio of emissions at $510 \mathrm{~nm}$ from excitation at 340 and $380 \mathrm{~nm}$. Ratio images were processed every $5 \mathrm{~s}$ and converted to $\left[\mathrm{Ca}^{2+}\right]_{\mathrm{c}}$ by comparison to a range of such ratios obtained by measurement of Fura- 2 in the presence of a known concentration of calcium (Calcium Calibration Buffer Kit; Molecular Probe, Eugene, OR, USA). Each experimental data point represents the mean $\left[\mathrm{Ca}^{2+}\right]_{c}$ calculated from at least 20-30 individually measured cells from three separate cultures. All imaging experiments were done at room temperature $\left(20-22^{\circ} \mathrm{C}\right)$.

\section{Measurement of ATP and ADP contents, and the} $A T P / A D P$ ratio in islets

ATP and ADP were assayed by luciferase measurement (Sigma), according to the manufacturer's protocol. ATP was assayed directly. For ADP measurements, ATP was first hydrolyzed to AMP with ATP sulfurylase. After inactivation of the sulfurylase, ADP was converted to ATP with pyruvate kinase and phosphoenolpyruvate, and was quantified by luciferase measurement (Schultz et al. 1993). To measure the immediate changes in ATP and ADP contents after high-glucose stimulation, islets were exposed to $15 \mathrm{mM}$ glucose for $3 \mathrm{~min}$ at $37^{\circ} \mathrm{C}$.

\section{Northern blotting}

The full-length cDNAs (mouse Kir6.2/pBF and rat SUR $1 / \mathrm{pBF}$ were kindly provided by Professor FM Ashcroft, and the human UCP2/pBS and SHP/pCDNA3 were kindly provided by Dr KU Lee and Dr HS Choi) were used as probes for Northern blot analysis. Radiolabeled probes were prepared by the random primer labeling method with $\left[\alpha-{ }^{32} \mathrm{P}\right] \mathrm{dCTP}$, using a random primer labeling kit (Amersham, Arlington Heights, IL, USA). After the labeling reaction, the radiolabeled probes were purified on a NAP-5 column (Pharmacia, Uppsala, Sweden). Total RNA for Northern analysis was extracted by the RNeasy RNA extraction kit (Qiagen, Hilden, Germany). Twenty micrograms of total RNA were applied to a $1 \%$ formaldehyde-agarose gel and transferred to a nylon membrane. The nylon membrane was hybridized in Express Hyb solution at $65^{\circ} \mathrm{C}$ for $2 \mathrm{~h}$ with a radiolabeled cDNA probe, and washed according to the 
manufacturer's instructions. The membrane was exposed to radiographic film for 24-48 h, and the mRNA expression was quantified with densitometric analysis.

\section{Western blot analysis}

INS-1 $\beta$-cells grown under different concentrations of glucose (3 or $15 \mathrm{mM}$ ) or INS-1 $\beta$-cells infected with adenovirus of human UCP2 $(1,10$, or $100 \mathrm{MOI})$ or null (100 MOI) were washed and lyzed in a buffer $(50 \mathrm{mM}$ Tris-Cl (pH 7•4), $150 \mathrm{mM} \mathrm{NaCl}$, 1\% Triton X-100, 1\% SDS, 1\% Nonidet P-40, 1 mM EDTA, $200 \mathrm{nM}$ aprotinin, $20 \mu \mathrm{M}$ leupeptin, $50 \mu \mathrm{M}$ phenanthroline and $280 \mu \mathrm{M}$ benzamidine- $\mathrm{HCl}$ ). After centrifugation, the supernatant was collected, and the protein concentration was determined. Equal amounts of protein were resolved by $10 \%$ SDS-polyacrylamide gel electrophoresis, and transferred onto a nitrocellulose membrane (Millipore, Bedford, MA, USA). The membrane was washed with Tris-buffered saline (TBS) $(10 \mathrm{mM}$ Tris and $150 \mathrm{mM} \mathrm{NaCl})$ containing $0.05 \%$ Tween 20 (TBST), and blocked in TBST containing $5 \%$ nonfat dried milk. The membrane was incubated with antibodies of UCP2 (1:1000, Alpha Diagnostic International, San Antonio, TX, USA) or actin (1:10 000; Sigma). After washing, the membrane was continuously incubated with appropriate secondary antibodies coupled to horseradish peroxidase, and developed in the ECL Western detection reagents.

\section{Statistical analysis}

Results are expressed as means \pm S.E.M., and significance was determined by Student's $t$-test for two-group comparisons or ANOVA for multiple-group comparison. $P<0 \cdot 05$ was considered significant.

\section{Results}

Intentional SHP overexpression does not modify the level of UCP2 expression

Northern blot analysis was first used to determine whether overexpression of SHP affects the expression level of UCP2 in normal or UCP2-overexpressing INS-1 $\beta$-cells. UCP2 mRNA levels were not changed when SHP was overexpressed in these cells (Fig. 1A). In addition, the mRNA levels of sulfonylurea receptor (SUR1) and inwardly rectifying $\mathrm{K}^{+}$channel (Kir6.2), which comprises $\mathrm{K}_{\mathrm{ATP}}$ channels in pancreatic or INS-1 $\beta$-cells, were not modified by intentional overexpression of the genes encoding UCP2, SHP or both. For endogenous overexpression of UCP2, INS-1 $\beta$-cells were infected with Ad-UCP2 $(1,10$ or 100 MOI) or Ad-Null (100 MOI only) in the presence of low glucose $(3 \mathrm{mM})$ for $24 \mathrm{~h}$. These infected cells were then grown under 3 or $15 \mathrm{mM}$ glucose for $48 \mathrm{~h}$. There was concentration-dependent increase of UCP2 expression in INS-1 $\beta$-cells when the concentrations of UCP2 virus were increased (Fig. 1B). To quantify the degree of adenoviral-mediated UCP2 overexpression in INS-1 $\beta$-cells, we treated Ad-Nullinfected INS-1 $\beta$-cells with high glucose $(15 \mathrm{mM})$ for $48 \mathrm{~h}$. There was about three- to fourfold more increased UCP2 expression in INS-1 $\beta$-cells infected with AdUCP2 (100 MOI) than the expression level of UCP2 induced by $15 \mathrm{mM}$ glucose in INS-1 $\beta$-cells (Fig. 1B). Interestingly, UCP2 expression induced by $50 \mathrm{MOI}$ of Ad-UCP2 was quantitatively similar to the endogenously expressed level of UCP2 induced by $15 \mathrm{mM}$ glucose (data not shown). It was previously suggested that if overexpressed UCP3 protein in the mitochondria could be eluted by high concentrations of nonionic detergents, such as Triton X-100, the protein would be functionally active (Guerini et al. 2002). Therefore, we applied this concept in our system where UCP2 is overexpressed in INS-1 or native $\beta$-cells. Most UCP 2 protein induced by Ad-UCP2 or by high glucose was solubilized by Triton X-100 from the mitochondria (data not shown), which was evaluated by the expression level of prohibitin (1:1000, NeoMarkers, Fremont, CA, USA), a mitochondria inner-membrane protein used as a control of the degree of solubility by Triton X-100, suggesting that overexpressed UCP2 in our system may be functional, as consistent with previous findings (Weber et al. 1997, Giannoukakis et al. 1999).

\section{GSIS is enhanced by SHP overexpression in normal islets}

In the cell-attached mode, bath application of $10 \mathrm{mM}$ glucose inhibited the single $\mathrm{K}_{\mathrm{ATP}}$ channel activity in both Ad-Null-infected control and Ad-SHP-infected $\beta$-cells (Fig. 2A and B). However, the extent of the channel inhibition, especially at the early period, was much greater in the Ad-SHP-infected group than in the Ad-Nullinfected group, implying an accelerated rate of glucosestimulated ATP production by SHP overexpression. The $\left[\mathrm{Ca}^{2+}\right]_{\mathrm{c}}$ increase in response to $10 \mathrm{mM}$ glucose was also potentiated in the Ad-SHP-infected group (Fig. 2C). There was no difference in basal insulin secretion at $5 \mathrm{mM}$ glucose between the two groups $(7 \cdot 2 \pm 3 \cdot 1$ in control vs $6 \cdot 1 \pm 1 \cdot 8$ (in Ad-SHP) $\mathrm{ng} / 10$ islets per $\mathrm{h}$ ), but insulin secretion in response to $10 \mathrm{mM}$ glucose was much greater in Ad-SHP-infected islets than in Ad-Null control $(28.6 \pm 5.2$ vs $18.3 \pm 4 \cdot 7)$ (Fig. $2 \mathrm{E}$ ). There was also no difference in glucose-mediated $\mathrm{K}_{\mathrm{ATP}}$ channel inhibition, $\left[\mathrm{Ca}^{2+}\right]_{c}$ increase and insulin secretion between no-virusinfected and Ad-Null-infected groups, suggesting that adenovirus infection itself has no significant effect on those parameters (Zhou et al. 2003).

Impaired GSIS in UCP2-overexpressing islets is recovered by overexpression of SHP

The same protocols of experiments were achieved on islet cells or islets overexpressing UCP2. The glucose-stimulated 
A
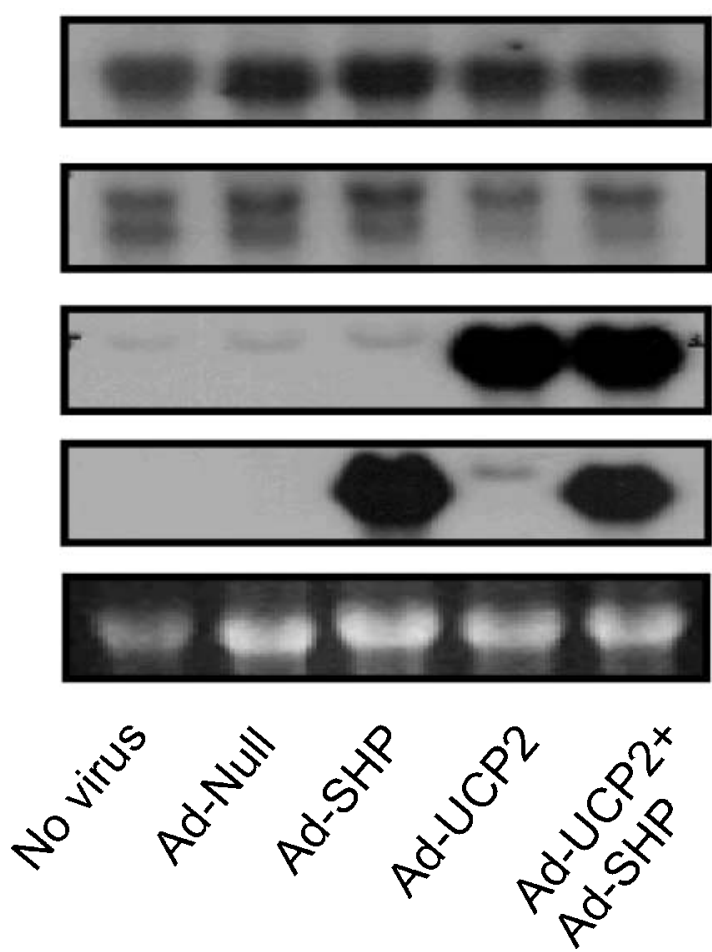

\section{SUR1}

Kir6.2

UCP2

SHP

$28 \mathrm{~S}$

B
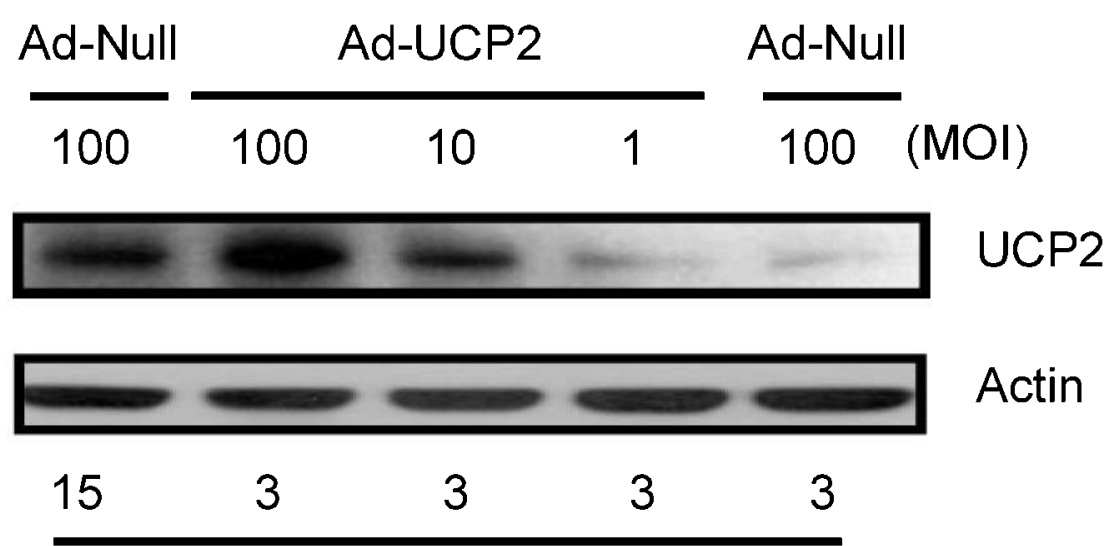

Actin

\section{Glucose (mM)}

Figure 1 Overexpression of UCP2 and/or SHP in INS-1 $\beta$-cells. (A) INS-1 $\beta$-cells were infected with either Ad-Null, Ad-SHP, Ad-UCP2 or Ad-UCP2+Ad-SHP. The cells were cultured in the presence of $3 \mathrm{mM}$ glucose and harvested $48 \mathrm{~h}$ after infection, and total RNA was isolated. Total RNA (20 $\mu \mathrm{g})$ was separated, transferred to a nylon membrane and probed with the respective radiolabeled cDNA. Equivalent loading of RNA was confirmed by $28 \mathrm{~S}$ rRNA. (B) Quantitative comparison of UCP2 protein expression induced by high glucose or different MOIs of Ad-UCP2 in INS-1 $\beta$-cells. INS-1 $\beta$-cells were infected with Ad-UCP2 $(1,10$ or $100 \mathrm{MOI})$ or Ad-Null $(100 \mathrm{MOI}$ only) in the presence of low glucose $(3 \mathrm{mM})$. At $24 \mathrm{~h}$ after infection, a group of Ad-Null-infected cells were further exposed to high glucose (15 mM) for $48 \mathrm{~h}$. Total cell lysates were prepared and analyzed for UCP2 or actin Western blot. 

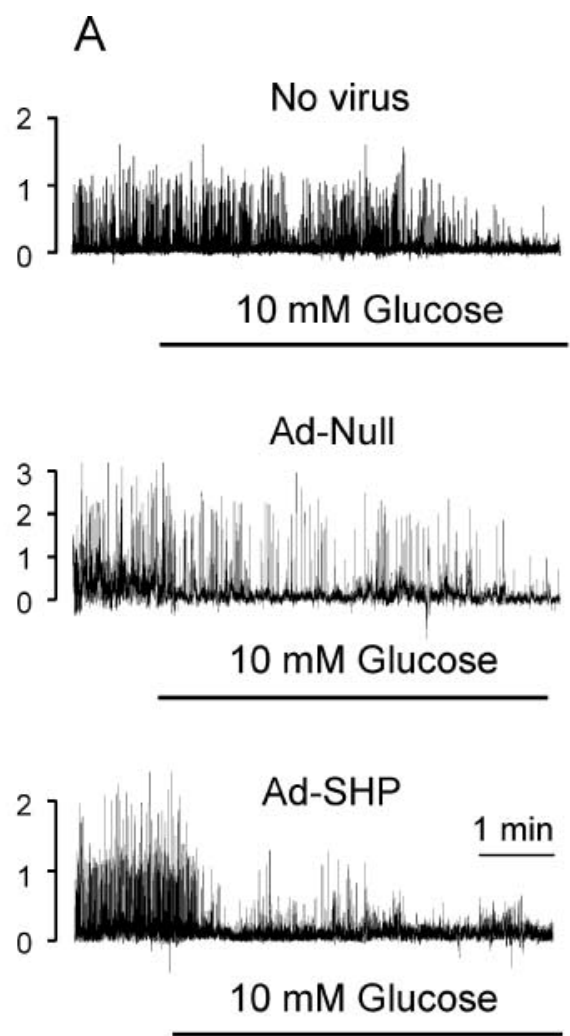

D

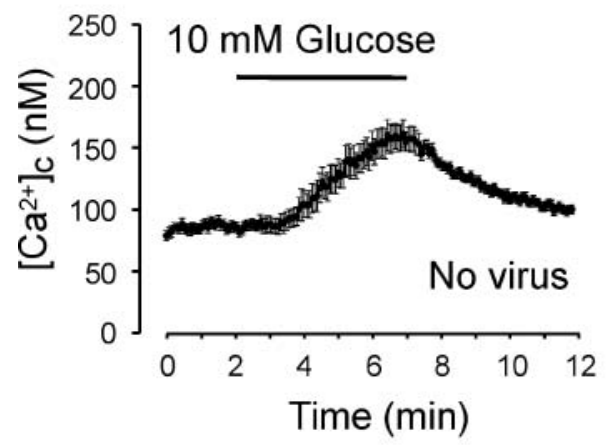

B

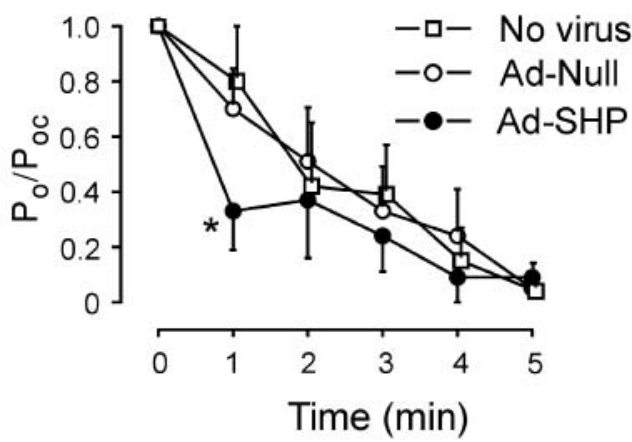

C

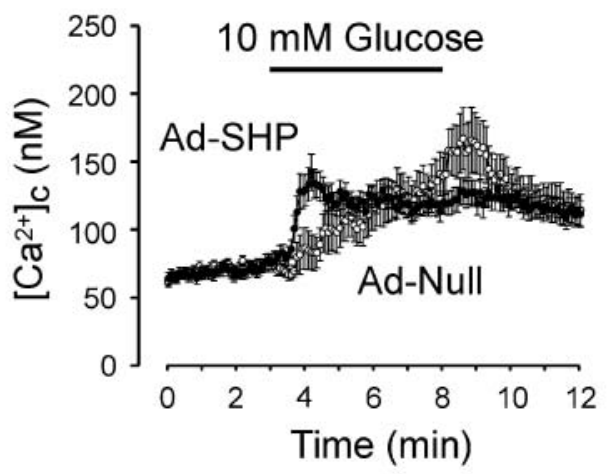

$E$

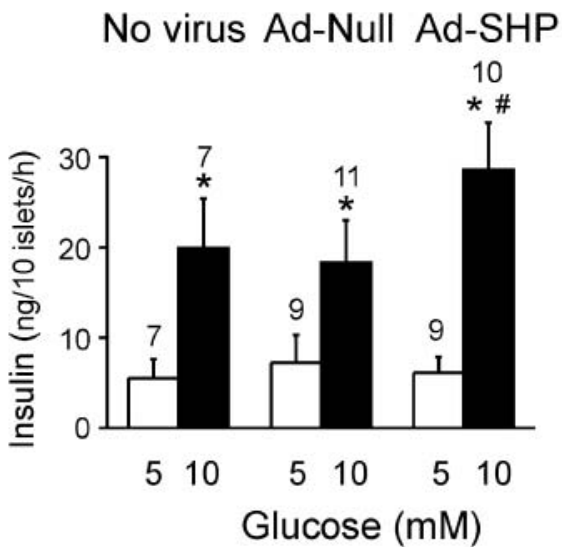

Figure 2 Effect of SHP overexpression on glucose sensitivity of islet cells. (A) Glucose-stimulated inhibition of single $\mathrm{K}_{\text {ATP }}$ channel currents in no-virus-infected $\beta$-cells, or Ad-Null- or Ad-SHP-infected $\beta$-cells.

Cell-attached mode was at a holding potential of $0 \mathrm{mV}$. The vertical scales indicate the number of channels. (B) Time course of the $\mathrm{K}_{\text {ATP }}$ channel inhibition by $10 \mathrm{mM}$ glucose in no-virus-infected $(n=5)$,

Ad-Null-infected $(n=6)$ or Ad-SHP-infected $(n=5) \beta$-cells. $P_{o}$ measured in the presence of $10 \mathrm{mM}$ glucose was normalized relative to $\mathrm{P}_{\mathrm{o}}$ measured immediately before exposure to glucose $\left(\mathrm{P}_{\mathrm{oc}}\right)$. ${ }^{*} \mathrm{P}<0.05$ compared with the values measured at the same time in the Ad-Null-infected group. Glucose-stimulated $\left[\mathrm{Ca}^{2+}\right]_{\mathrm{C}}$ increase in Ad-Null-infected islet cells $(n=23)$, Ad-SHP-infected islet cells $(n=17)(C)$ or no-virus-infected islet cells $(n=21)$ (D). Insulin secretion in response to glucose from islets of no-virus-infected,

Ad-Null-infected or Ad-SHP-infected group (E). The number of data points ( $n$ ) given above each bar was obtained from at least three separate experiments. ${ }^{*} P<0.05$ compared with the values measured at $5 \mathrm{mM}$ glucose in the same group. ${ }^{\#} P<0.05$ compared with the values measured at $10 \mathrm{mM}$ glucose in the Ad-Null-infected group. The symbols represent the means \pm S.E.M. 

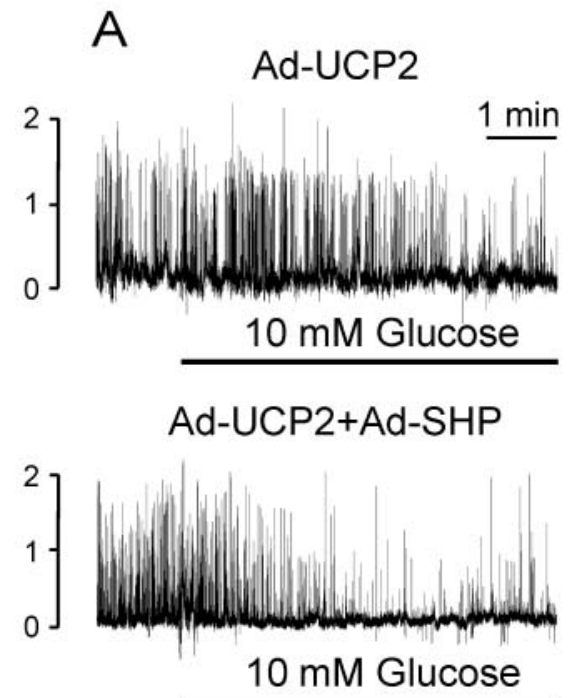

C

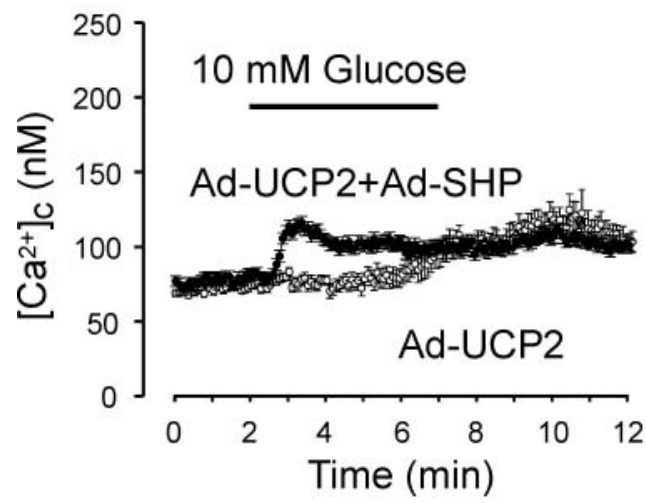

B
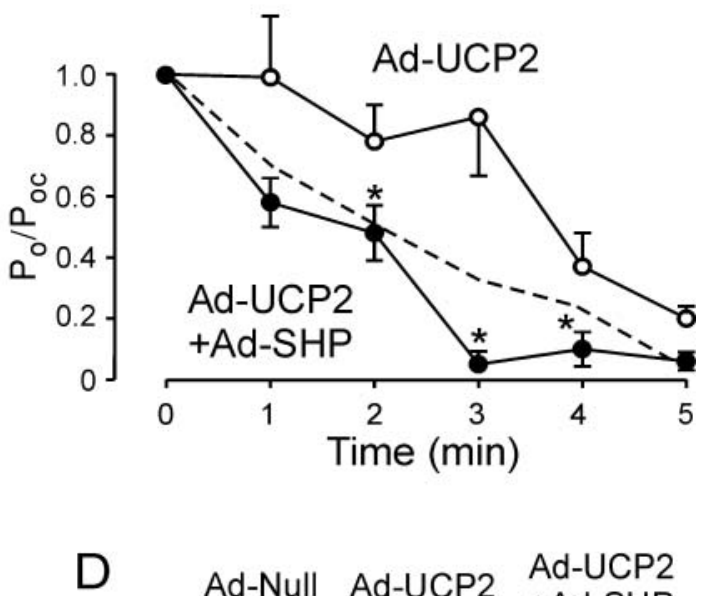

Ad-Null Ad-UCP2
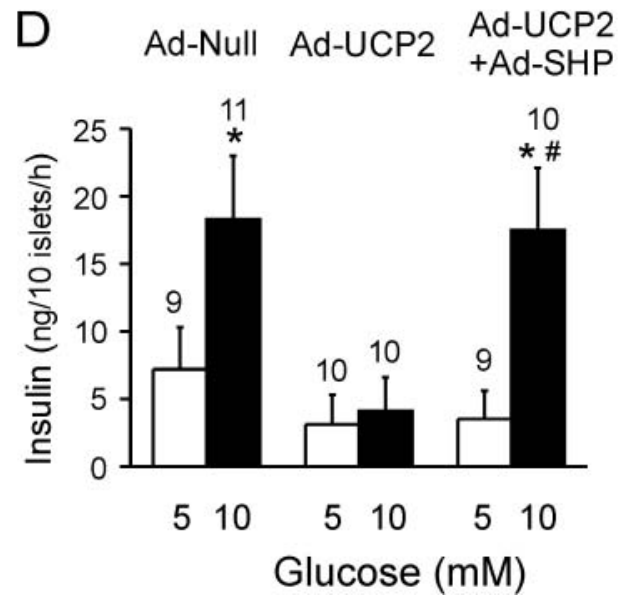

Figure 3 Effect of SHP overexpression on glucose sensitivity of UCP2-overexpressing islet cells. (A) Glucose-stimulated inhibition of single $\mathrm{K}_{\text {ATP }}$ channel currents in Ad-UCP2-infected $\beta$-cells or Ad-UCP2+Ad-SHP-infected $\beta$-cells. Cell-attached mode at a holding potential of $0 \mathrm{mV}$. The vertical scales indicate the number of channels. (B) Time course of the $K_{\text {ATP }}$ channel inhibition by $10 \mathrm{mM}$ glucose in Ad-UCP2- $(n=5)$ or Ad-UCP2+Ad-SHP-infected $(n=7) \beta$-cells. The result from the Ad-Null group in Fig. 2 is shown by the dashed line. $P_{0}$ measured in the presence of $10 \mathrm{mM}$ glucose was normalized relative to $P_{0}$ measured immediately before exposure to glucose $\left(\mathrm{P}_{\mathrm{oc}}\right)$. ${ }^{*} P<0.05$ compared with the values measured at the same time in Ad-UCP2-infected group. (C) Glucose-stimulated $\left[\mathrm{Ca}^{2+}\right]_{\mathrm{C}}$ increase in Ad-UCP2- $(n=15)$ or Ad-UCP2+Ad-SHP-infected $(n=21)$ islet cells. (D) Insulin secretion from islets of Ad-UCP2- or Ad-UCP2+Ad-SHP-infected group. The result from the Ad-Null group in Fig. 2 is also shown (left bars). The number of data points $(n)$ given above each bar was obtained from at least three separate experiments. ${ }^{*} P<0 \cdot 05$ compared with the values measured at $5 \mathrm{mM}$ glucose in the same group. ${ }^{\#} P<0 \cdot 05$ compared with the values measured at $10 \mathrm{mM}$ glucose in the Ad-UCP2-infected group. The symbols represent means \pm S.E.M.

$\mathrm{K}_{\mathrm{ATP}}$-channel inhibition in Ad-UCP2-infected $\beta$-cells was considerably impaired (Fig. 3A and B). They also failed to elicit glucose-stimulated $\left[\mathrm{Ca}^{2+}\right]_{\mathrm{c}}$ increase (Fig. 3C) and insulin secretion (Fig. 3D) during the experiments. However, the impaired high-glucose sensitivities were significantly recovered by simultaneous overexpression of SHP and UCP2, comparable to Ad-Null-infected cells.
SHP overexpression restores glucose-stimulated ATP production and the $A T P / A D P$ ratio in $U C P 2$-overexpressing islets

ATP and ADP levels and the ATP/ADP ratio among no-virus-infected islets, and Ad-Null- and Ad-SHPinfected islets were not different when measured after 48 - $\mathrm{h}$ culture in the presence of $5 \mathrm{mM}$ glucose (Table 1). 
Table 1 Effect of SHP on ATP and ADP levels and the ATP/ADP ratios in normal or UCP2-overexpressing islets. For measurement of the immediate changes in ATP and ADP contents after high-glucose stimulation, islets were exposed to $15 \mathrm{mM}$ glucose for $3 \mathrm{~min}$ at $37^{\circ} \mathrm{C}$. Values are means \pm S.E.M. of three independent experiments. ${ }^{\#} P$ 0.05; ${ }^{*} P 0.05$ compared to Ad-Null group; ${ }^{\dagger} P$ compared to Ad-UCP2 group

\begin{tabular}{|c|c|c|c|c|c|}
\hline & No virus & Ad-Null & Ad-SHP & Ad-UCP2 & Ad-UCP2+Ad-SHP \\
\hline \multicolumn{6}{|l|}{ Glucose, $5 \mathrm{mM}$} \\
\hline ATP, pM/islet & $5 \cdot 3 \pm 1 \cdot 5$ & $5 \cdot 1 \pm 1 \cdot 4$ & $4 \cdot 7 \pm 2 \cdot 1$ & $3 \cdot 3 \pm 1 \cdot 2^{*}$ & $6 \cdot 0 \pm 1 \cdot 4^{\dagger}$ \\
\hline ADP, $\mathrm{pM}$ /islet & $4 \cdot 7 \pm 0 \cdot 5$ & $4 \cdot 6 \pm 0 \cdot 7$ & $4 \cdot 1 \pm 0 \cdot 4$ & $4 \cdot 9 \pm 0 \cdot 5$ & $4 \cdot 3 \pm 0 \cdot 3$ \\
\hline ATP/ADP ratio & $1 \cdot 1 \pm 0 \cdot 3$ & $1 \cdot 1 \pm 0 \cdot 3$ & $1 \cdot 1 \pm 0 \cdot 5$ & $0 \cdot 7 \pm 0 \cdot 3^{*}$ & $1 \cdot 4 \pm 0 \cdot 3^{\dagger}$ \\
\hline \multicolumn{6}{|l|}{ Glucose $15 \mathrm{mM}$} \\
\hline ATP, pM/islet & $7 \cdot 9 \pm 2 \cdot 1$ & $8 \cdot 0 \pm 1 \cdot 7$ & $12 \cdot 1 \pm 2 \cdot 8^{\#}$ & $4 \cdot 5 \pm 0 \cdot 3^{*}$ & $9 \cdot 5 \pm 1.9^{\dagger}$ \\
\hline ADP, pM/islet & $3 \cdot 3 \pm 0 \cdot 5$ & $3 \cdot 7 \pm 0 \cdot 6$ & $2 \cdot 9 \pm 0 \cdot 3$ & $4 \cdot 2 \pm 0 \cdot 8^{*}$ & $3 \cdot 0 \pm 0 \cdot 4$ \\
\hline ATP/ADP ratio & $2 \cdot 4 \pm 0 \cdot 5$ & $2 \cdot 2 \pm 0 \cdot 4$ & $4 \cdot 2 \pm 0 \cdot 8^{\#}$ & $1 \cdot 1 \pm 0 \cdot 4^{*}$ & $3 \cdot 2 \pm 0 \cdot 9^{\dagger}$ \\
\hline
\end{tabular}

However, Ad-UCP2-infected islets exhibited lower ATP level and ATP/ADP ratio than Ad-Null-infected islets. These impaired parameters were significantly improved in the Ad-UCP2+Ad-SHP-infected group. After high glucose stimulation for $3 \mathrm{~min}$, increases of ATP content and the ATP/ADP ratio in Ad-SHP-infected group were significantly greater than in the Ad-Null-infected group $(P<0 \cdot 05)$. In the Ad-UCP2-infected group, ATP contents and the ATP/ADP ratio were remarkably lower, but they were restored in the Ad-UCP2+Ad-SHP-infected group, comparably to the Ad-Null-infected group.

The mechanism of SHP action on GSIS is not associated with the glycolytic pathway

To rule out the possibility that SHP affects certain steps of glycolysis, we used another insulin secretagogue, methylpyruvate, which bypasses the cytosolic glycolytic pathway and thus directly participates in mitochondrial oxidative phosphorylation to produce ATP (Dukes et al. 1998). The impaired methylpyruvate sensitivities of the AdUCP2-infected group were significantly recovered by concomitant SHP overexpression (Fig. 4), indicating that sites responsible for the SHP action are downstream of glycolysis.

\section{Dihydroxyacetone-induced $K_{A T P}$ channel inhibition}

Dihydroxyacetone (DHA) gives FADH2 to complex II of the mitochondrial electron transport system directly through the glycerophosphate shuttle, bypassing the Krebs cycle (Song et al. 1997). To elucidate the cause of reduced GSIS in UCP2-overexpressing islets, we tested the DHAinduced $\mathrm{K}_{\mathrm{ATP}}$ channel inhibition in Ad-UCP2- and AdNull-infected $\beta$-cells. Our hypothesis was that if the $\mathrm{K}_{\text {ATP }}$ channel inhibition was normal in Ad-UCP2-infected $\beta$-cells, the sites responsible for the impairment of highglucose sensitivity, that is, those responsible for reduced ATP production by Ad-UCP2 infection, could be within the Krebs cycle upstream of the electron transport system.
In fact, $20 \mathrm{mM}$ of DHA externally applied inhibited the $\mathrm{K}_{\mathrm{ATP}}$ channel activity in Ad-UCP2-infected $\beta$-cells to the same extent as in Ad-Null-infected controls (Fig. 5A), being able to show downward spikes as an indirect evidence of cellular depolarization in the cell-attached mode (Song et al. 1997). This finding revealed that a defect of GSIS in UCP2-overexpressing $\beta$-cells may be due to not only UCP2-mediated proton leak in response to incoming reducing equivalents, but also reduced metabolism of glucose metabolites in the Krebs cycle secondary to UCP2 overexpression. Moreover, SHP overexpression did not further increase the DHA-mediated $\mathrm{K}_{\mathrm{ATP}}$ channel inhibition, suggesting that SHP exerts its effect in the Krebs cycle followed by the electron transport system. Figure 5B illustrates the changes in GSIS after pretreatment with $3 \mathrm{mM}$ sodium azide, a mitochondrial metabolic inhibitor. Sodium azide remarkably inhibited the increasing effect of SHP on GSIS in the Ad-SHP- and AdUCP2+Ad-SHP-infected groups compared with the AdNull and Ad-UCP2 groups respectively, indicating that mitochondrial metabolism is critical for the glucoseinduced insulinotropic effect of SHP.

\section{PPAR $\gamma$ activation is not critical for the SHP effect on GSIS}

To investigate whether the potential activation of PPAR $\gamma$ by intentional SHP overexpression affects GSIS or not, we pretreated islets with $10 \mu \mathrm{M}$ GW9662, a PPAR $\gamma$ antagonist, at the time when Ad-UCP2 and Ad-SHP were introduced in the media containing islets. The increase of GSIS by SHP in Ad-UCP2-infected islets was not attenuated by the pretreatment of GW9662 (Fig. 6), excluding that the effect of SHP on GSIS increase is mediated through PPAR $\gamma$ activation.

\section{Discussion}

Impaired glucose sensitivity of $\beta$-cells is a major cause of prolonged postprandial hyperglycemia (Pratley \& Weyer 
A
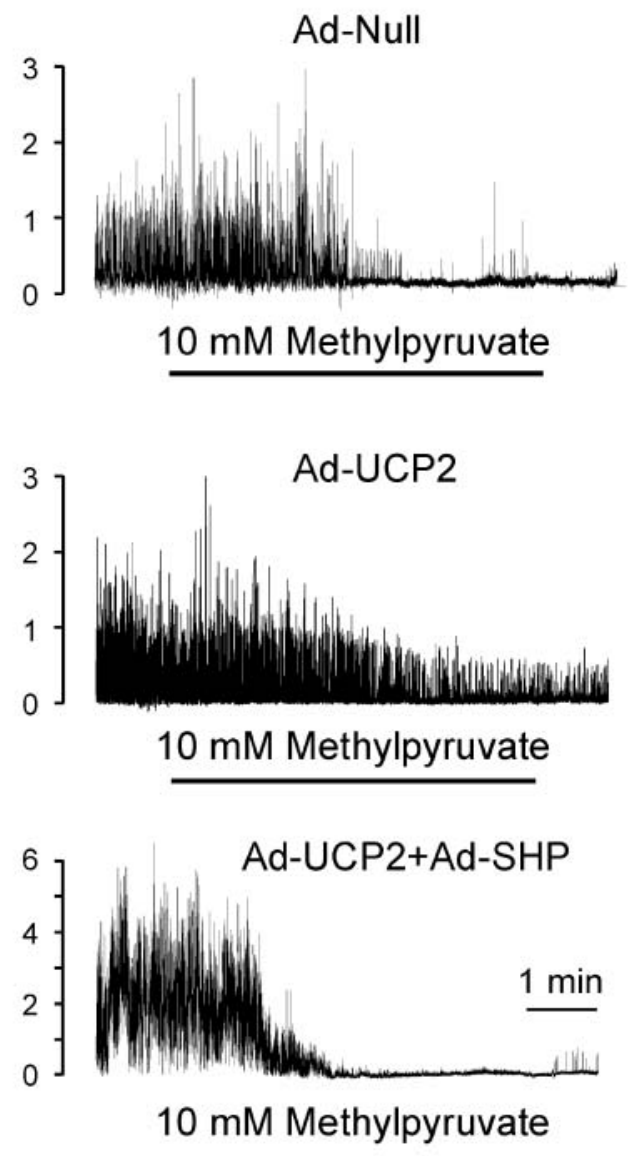

B
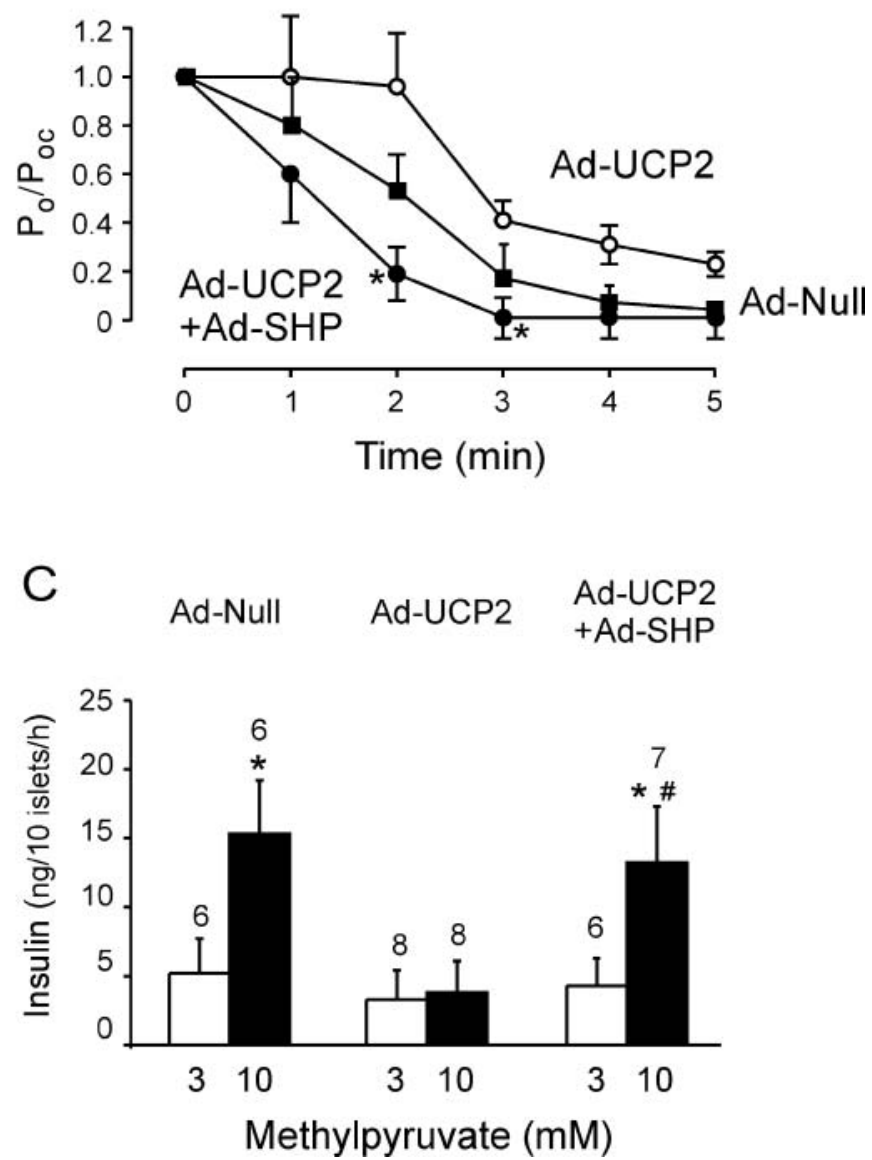

Figure 4 Effect of SHP overexpression on methylpyruvate sensitivity of UCP2-overexpressing islet cells. (A) Methylpyruvate-stimulated inhibition of single $K_{\text {ATP }}$ channel currents in Ad-Null-infected, Ad-UCP2-infected or Ad-UCP2+Ad-SHP-infected $\beta$-cells. Cell-attached mode at a holding potential of $0 \mathrm{mV}$. The vertical scales indicate the number of channels. (B) Time course of the $\mathrm{K}_{\mathrm{ATP}}$ channel inhibition by $10 \mathrm{mM}$ methylpyruvate in Ad-Null-infected $(n=4)$, Ad-UCP2-infected $(n=5)$ or Ad-UCP2+Ad-SHP-infected $(n=5) \quad \beta$-cells. $\mathrm{P}_{\mathrm{o}}$ measured in the presence of $10 \mathrm{mM}$ methylpyruvate was normalized relative to the $\mathrm{P}_{\mathrm{o}}$ measured immediately before exposure to methylpyruvate $\left(\mathrm{P}_{\mathrm{oc}}\right)$. ${ }^{*} P<0.05$ compared with the values measured at the same time in the Ad-UCP2-infected group. (C) Insulin secretion in response to methylpyruvate from islets of Ad-Null-, Ad-UCP2- or Ad-UCP2+Ad-SHP-infected group. The number of data points $(n)$ given above each bar was obtained from at least three separate experiments. ${ }^{*} P<0.05$ compared with the values measured at 3 mM methylpyruvate in the same group. ${ }^{\# P}<0.05$ compared with the values measured at $10 \mathrm{mM}$ methylpyruvate in the Ad-UCP2-infected group. The symbols represent means \pm S.E.M.

2001). Tissues chronically exposed to elevated glucose and free fatty acid levels (Bruce et al. 1988) develop various diabetic complications. Since the GSIS defect can be readily observed in subjects at high risk of developing diabetes (Yalow \& Berson 1960), early correction is important for prevention and treatment of diabetes.

MODY-3 patients lacking dominant HNF1 $\alpha$ function manifest a considerable proportion of SHP mutations with reduced GSIS, insulin synthesis and $\beta$-cell differentiation (Shih et al. 2001). The mechanism of action of HNF1 $\alpha$ associated with GSIS, however, seems to involve the glycolytic pathway upstream of mitochondrial oxidative metabolism.
Here we showed that an orphan nuclear receptor, SHP, positively regulated GSIS when overexpressed in islets. $\mathrm{K}_{\text {ATP }}$ channel inhibition and substantial ATP production following high glucose exposure were also enhanced by SHP overexpression. Moreover, SHP overexpression improved impaired GSIS in UCP2-overexpressing islets. We examined whether, like UCP2, SHP action was associated with mitochondrial metabolic activity. When Ad-UCP2-infected islets were stimulated with methylpyruvate, another energy fuel that bypasses glycolysis, insulin secretion was impaired, and this impairment was restored by SHP overexpression. Furthermore, when stimulated with DHA that bypasses both glycolysis and the 
A
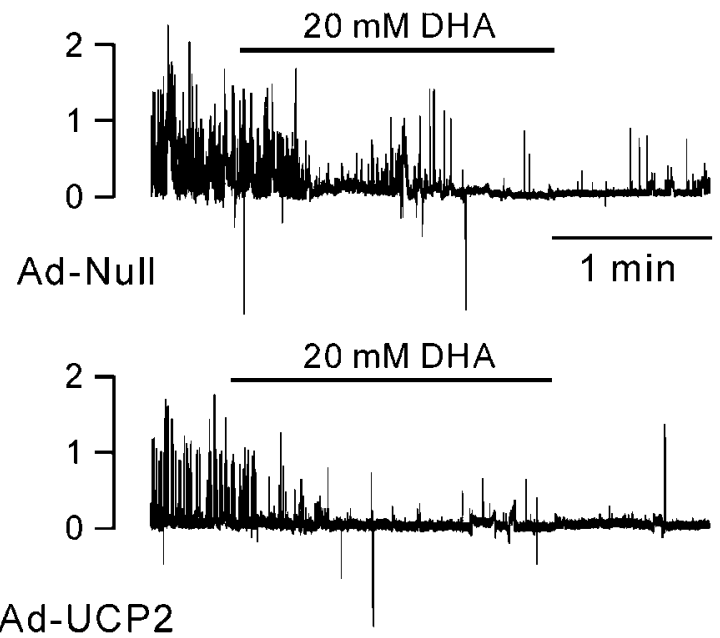

Ad-UCP2

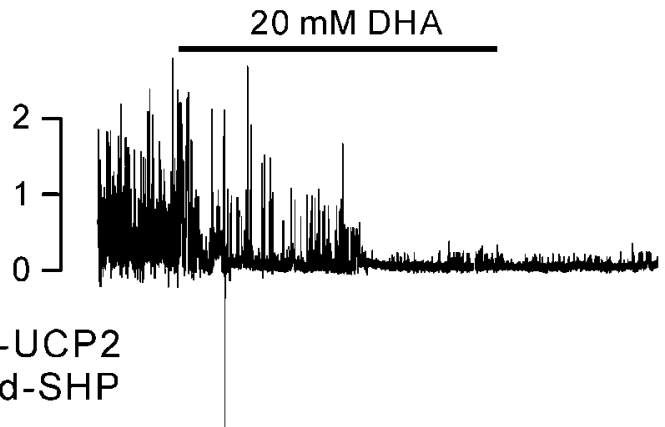

B

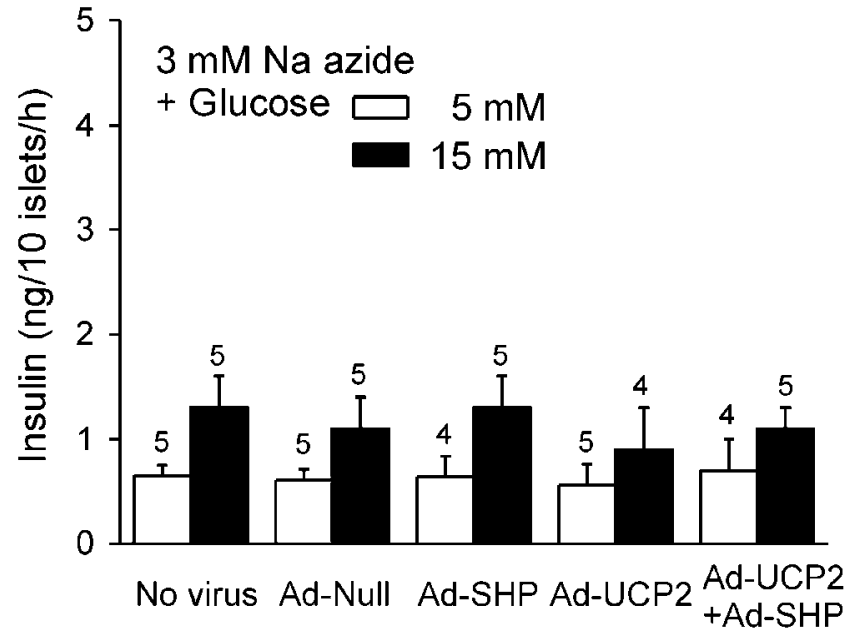

Figure 5 Dihydroxyacetone (DHA)-stimulated $\mathrm{K}_{\mathrm{ATP}}$ channel inhibition in Ad-Null-, Ad-UCP2- or Ad-UCP2+Ad-SHP-infected $\beta$-cells. (A) Cell-attached mode at a membrane potential of $0 \mathrm{mV}$. DHA $(20 \mathrm{mM})$ was applied to the bath solution as indicated by the bars. The vertical scales indicate the number of channels. The downward spikes representing cellular depolarization are also shown. (B) Effects of pretreatment with a mitochondrial metabolic inhibitor sodium azide $(3 \mathrm{mM})$ on insulin secretion in response to glucose in no-virus-infected, Ad-Null, Ad-SHP, Ad-UCP2 or Ad-UCP2+Ad-SHP group. The number of data points $(n)$ given above each bar was obtained from at least three separate experiments. The symbols represent means \pm S.E.M.

Krebs cycle to produce ATP, no defect in DHA-induced $\mathrm{K}_{\mathrm{ATP}}$ channel inhibition was observed in Ad-UCP2infected cells compared with Ad-Null- and Ad-UCP2+ Ad-SHP-infected cells. These data suggest that the metabolic sites impaired by UCP2 and restored by SHP are within the Krebs cycle downstream of glycolysis and upstream of the electron transport system. Further evidence for this proposal was that sodium azide, a mitochondrial metabolic inhibitor, totally blocked SHP-mediated increases in insulin responses in Ad-Null-infected and Ad-UCP2-infected cells.

$\beta$-cell mitochondrial metabolism is closely linked to insulin secretion via changes in the ATP/ADP ratio. It appears that nuclear receptors in $\beta$-cells can modulate transcription of mitochondrial metabolic enzyme genes (Ogata et al. 2002). Indeed, inhibition of nuclear receptor HNF1 $\alpha$ activity in $\beta$-cells reduced expression of genes related to mitochondrial energy metabolism, but dramati- cally increased mitochondrial UCP2 mRNA and protein levels (Wang et al. 2000). A major aim of future studies should be to identify mitochondrial metabolism genes or proteins whose expression is regulated by SHP.

Brown et al. (1999) demonstrated that the tyrosinebased PPAR $\gamma$ agonist GW1929 restored biphasic insulin secretion in a glucose-dependent manner in Zücker diabetic fatty rats. Yajima et al. (2003) reported that pioglitazone, another PPAR $\gamma$ agonist, restored GSIS in $d b / d b$ mice. However, the increased GSIS following SHP overexpression shown in the present study was not likely to be due to SHP-induced PPAR $\gamma$ activation since the PPAR $\gamma$ antagonist GW9662 did not prevent this increase. Consistent with this finding, a recent report showed that overexpression of the PPAR $\gamma$ coactivator (PGC) $-1 \alpha$, which shares with SHP the ability to increase PPAR $\gamma$ activity, decreased GSIS in islets in vitro and in live mice (Yoon et al. 2003). 


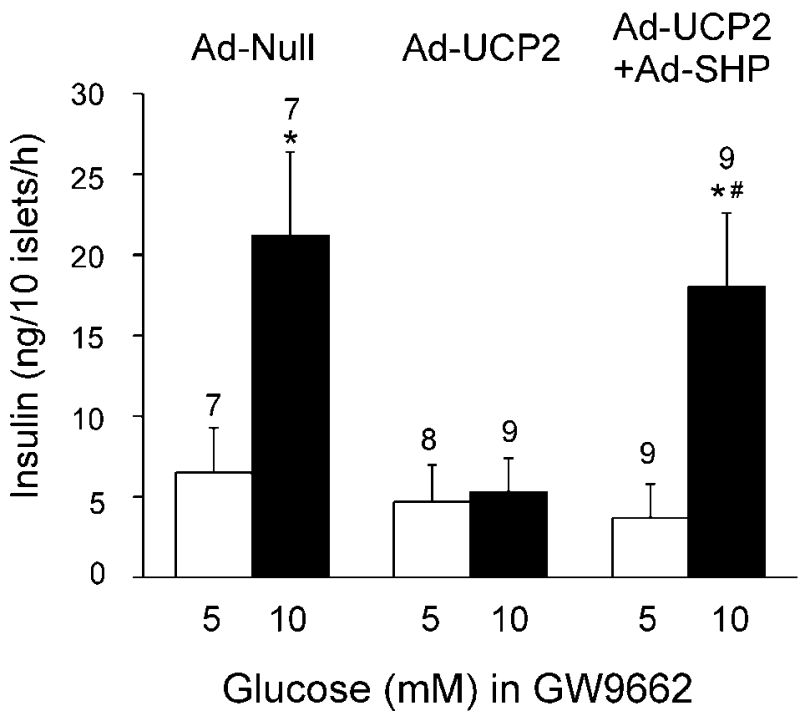

Figure 6 Effect of a PPAR $\gamma$ antagonist GW9662 on GSIS from islets infected with Ad-Null, Ad-UCP2 or Ad-UCP2+Ad-SHP. The islets were initially pretreated with GW9662 $(10 \mu \mathrm{M})$ and then exposed to 5 or $10 \mathrm{mM}$ glucose, followed by measurement of insulin secretion in these cells. The number of data points $(n)$ given above each bar was obtained from at least three separate experiments. ${ }^{*} P<0 \cdot 05$ compared with the values measured at $5 \mathrm{mM}$ glucose in the same group. ${ }^{\#} P<0.05$ compared with the values measured at $10 \mathrm{mM}$ glucose in the Ad-UCP2-infected group. The symbols represent means \pm S.E.M.

In conclusion, the present data indicate that SHP overexpression in $\beta$-cells increases GSIS through increasing the ATP/ADP ratio rather than through transcriptional activation of PPAR $\gamma$. This study suggests that modulators which can upregulate SHP expression and/or potentiate SHP transcriptional activation activity may be new therapeutic candidates for improving glucose sensitivity in diabetic $\beta$-cells.

\section{Acknowledgement}

This work was supported by grant No. R13-2002-02801003-0 from the Basic Research Program of KOSEF.

\section{References}

Asfari M, Janjic D, Meda P, Li G, Halban PA \& Wollheim CB 1992 Establishment of 2-mercaptoethanol-dependent differentiated insulin-secreting cell lines. Endocrinology 130 167-178.

Bae JH, Park JW \& Kwon TK 2003 Ruthenium red, inhibitor of mitochondrial $\mathrm{Ca}^{2+}$ uniporter, inhibits curcumin-induced apoptosis via the prevention of intracellular $\mathrm{Ca}^{2+}$ depletion and cytochrome $\mathrm{c}$ release. Biochemical and Biophysical Research Communications 303 1073-1079.

Barroso I, Gurnell M, Crowley VE, Agostini M, Schwabe JW, Soos MA, Maslen GL, Williams TD, Lewis H, Schafer AJ, Chatterjee VK \& O'Rahilly S 1999 Dominant negative mutations in human
PPAR $\gamma$ associated with severe insulin resistance, diabetes mellitus and hypertension. Nature 402 880-883.

Brown KK, Henke BR, Blanchard SG, Cobb JE, Mook R, Kaldor I, Kliewer SA, Lehmann JM, Lenhard JM, Harrington WW, Novak PJ, Faison W, Binz JG, Hashim MA, Oliver WO, Brown HR, Parks DJ, Plunket KD, Tong WQ, Menius JA, Adkison K, Noble SA \& Willson TM 1999 A novel $N$-aryl tyrosine activator of peroxisome proliferator-activated receptor- $\gamma$ reverses the diabetic phenotype of the Zücker diabetic fatty rat. Diabetes $\mathbf{4 8}$ 1415-1424.

Bruce DG, Chisholm DJ, Storlien LH \& Kraegen EW 1988 Physiological importance of deficiency in early prandial insulin secretion in non-insulin-dependent diabetes. Diabetes 37 736-744.

Chan CB, MacDonald PE, Saleh MC, Johns DC, Marban E \& Wheeler MB 1999 Overexpression of uncoupling protein 2 inhibits glucose-stimulated insulin secretion from rat islets. Diabetes $\mathbf{4 8}$ $1482-1486$.

Chan CB, De Leo D, Joseph JW, McQuaid TS, Ha XF, Xu F, Tsushima RG, Pennefather PS, Salapatek AM \& Wheeler MB 2001 Increased uncoupling protein-2 levels in $\beta$-cells are associated with impaired glucose-stimulated insulin secretion: mechanism of action. Diabetes $\mathbf{5 0}$ 1302-1310.

Choi YK, Kim YJ, Park HS, Choi K, Paik SG, Lee YI \& Park JG 2003 Suppression of glomerulosclerosis by adenovirus-mediated IL-10 expression in the kidney. Gene Therapy 10 559-568.

Day C 1999 Thiazolidinediones: a new class of antidiabetic drugs. Diabetic Medicine 16 179-192.

DeFronzo RA 1988 Lilly lecture 1987. The triumvirate: $\beta$-cell, muscle, liver. A collusion responsible for NIDDM. Diabetes 37 667-687.

Dukes ID, Sreenan S, Roe MW, Levisetti M, Zhou YP, Ostrega D, Bell GI, Pontoglio M, Yaniv M, Philipson L \& Polonsky KS 1998 Defective pancreatic $\beta$-cell glycolytic signaling in hepatocyte nuclear factor-1 $\alpha$-deficient mice. Journal of Biological Chemistry 273 24457-24464.

Echtay KS, Roussel D, St-Pierre J, Jekabsons MB, Cadenas S, Stuart JA, Harper JA, Roebuck SJ, Morrison A, Pickering S, Clapham JC \& Brand MD 2002 Superoxide activates mitochondrial uncoupling proteins. Nature 415 96-99.

Giannoukakis N, Rudert WA, Ghivizzani SC, Gambotto A, Ricordi C, Trucco M \& Robbins PD 1999 Adenoviral gene transfer of the interleukin-1 receptor antagonist protein to human islets prevents IL-1 $\beta$-induced beta-cell impairment and activation of islet cell apoptosis in vitro. Diabetes 48 1730-1736.

Goodwin B, Jones SA, Price RR, Watson MA, McKee DD, Moore LB, Galardi C, Wilson JG, Lewis MC, Roth ME, Maloney PR, Willson TM \& Kliewer SA 2000 A regulatory cascade of the nuclear receptors FXR, SHP-1, and LRH-1 represses bile acid biosynthesis. Molecular Cell 6 517-526.

Graham FL \& van der Eb AJ 1973 A new technique for the assay of infectivity of human adenovirus 5 DNA. Virology 52 456-467.

Guerini D, Prati E, Desai U, Nick HP, Flammer R, Gruninger S, Cumin F, Kaleko M, Connelly S \& Chiesi M 2002 Uncoupling of protein-3 induces an uncontrolled uncoupling of mitochondria after expression in muscle derived L6 cells. European Journal of Biochemistry 269 1373-1381.

Hamill OP, Marty A, Neher E, Sakmann B \& Sigworth FJ 1981 Improved patch-clamp techniques for high-resolution current recording from cells and cell-free membrane patches. Pflügers Archiv - European Journal of Physiology 391 85-100.

Johansson L, Thomsen JS, Damdimopoulos AE, Spyrou G, Gustafsson JA \& Treuter E 1999 The orphan nuclear receptor SHP inhibits agonist-dependent transcriptional activity of estrogen receptors ER $\alpha$ and ER $\beta$. Journal of Biological Chemistry 274 345-353.

Lee HK, Lee YK, Park SH, Kim YS, Lee JW, Kwon HB, Soh J, Moore DD \& Choi HS 1998 Structure and expression of the orphan nuclear receptor SHP gene. Journal of Biological Chemistry 273 14398-14402. 
Lee YK, Dell H, Dowhan DH, Hadzopoulou-Cladaras M \& Moore DD 2000 The orphan nuclear receptor SHP inhibits hepatocyte nuclear factor 4 and retinoid $\mathrm{X}$ receptor transactivation: two mechanisms for repression. Molecular and Cellular Biology 20 187-195.

McCormack JG, Halestrap AP \& Denton RM 1990 Role of calcium ions in regulation of mammalian intramitochondrial metabolism. Physiological Review 70 391-425.

Mitchell SM, Weedon MN, Owen KR, Shields B, Wilkins-Wall B, Walker M, McCarthy MI, Frayling TM \& Hattersley AT 2003 Genetic variation in the small heterodimer partner gene and young-onset type 2 diabetes, obesity, and birth weight in U.K. Subjects. Diabetes 52 1276-1279.

Nishigori H, Tomura H, Tonooka N, Kanamori M, Yamada S, Sho K, Inoue I, Kikuchi N, Onigata K, Kojima I, Kohama T, Yamagata K, Yang Q, Matsuzawa Y, Miki T, Seino S, Kim MY, Choi HS, Lee YK, Moore DD \& Takeda J 2001 Mutations in the small heterodimer partner gene are associated with mild obesity in Japanese subjects. PNAS 98 575-580.

Nishizawa H, Yamagata K, Shimomura I, Takahashi M, Kuriyama H, Kishida K, Hotta K, Nagaretani H, Maeda N, Matsuda M, Kihara S, Nakamura T, Nishigori H, Tomura H, Moore DD, Takeda J, Funahashi T \& Matsuzawa Y 2002 Small heterodimer partner, an orphan nuclear receptor, augments peroxisome proliferator-activated receptor $\gamma$ transactivation. Journal of Biological Chemistry 277 $1586-1592$.

Ogata M, Awaji T, Iwasaki N, Miyazaki S, Bell GI \& Iwamoto Y 2002 Nuclear translocation of SHP and visualization of interaction with HNF-4 $\alpha$ in living cells. Biochemical and Biophysical Research Communications 292 8-12.

Patane G, Anello M, Piro S, Vigneri R, Purrello F \& Rabuazzo AM 2002 Role of ATP production and uncoupling protein-2 in the insulin secretory defect induced by chronic exposure to high glucose or free fatty acids and effects of peroxisome proliferator-activated receptor- $\gamma$ inhibition. Diabetes 51 2749-2756.

Pratley RE \& Weyer C 2001 The role of impaired early insulin secretion in the pathogenesis of type II diabetes mellitus. Diabetologia 44 929-945.

Rutter GA, Burnett P, Rizzuto R, Brini M, Murgia M, Pozzan T, Tavare JM \& Denton RM 1996 Subcellular imaging of intramitochondrial $\mathrm{Ca}^{2+}$ with recombinant targeted aequorin: significance for the regulation of pyruvate dehydrogenase activity. PNAS 93 5489-5494.

Schultz V, Sussman I, Bokvist K \& Tornheim K 1993 Bioluminometric assay of $\mathrm{ADP}$ and $\mathrm{ATP}$ at high $\mathrm{ATP} / \mathrm{ADP}$ ratios: assay of ADP after enzymatic removal of ATP. Analytical Biochemistry 215 302-304.

Schwanstecher C, Meyer U \& Schwanstecher M 2002 KIR6.2 polymorphism predisposes to type 2 diabetes by inducing overactivity of pancreatic $\beta$-cell ATP-sensitive $\mathrm{K}^{+}$channels. Diabetes $\mathbf{5 1} 875-879$.

Seol W, Choi HS \& Moore DD 1996 An orphan nuclear hormone receptor that lacks a DNA binding domain and heterodimerizes with other receptors. Science 272 1336-1339.

Seol W, Chung M \& Moore DD 1997 Novel receptor interaction and repression domains in the orphan receptor SHP. Molecular and Cellular Biology 17 7126-7131.

Seol W, Hanstein B, Brown M \& Moore DD 1998 Inhibition of estrogen receptor action by the orphan receptor SHP (short heterodimer partner). Molecular Endocrinology 12 1551-1557.
Shih DQ, Screenan S, Munoz KN, Philipson L, Pontoglio M, Yaniv M, Polonsky KS \& Stoffel M 2001 Loss of HNF-1 $\alpha$ function in mice leads to abnormal expression of genes involved in pancreatic islet development and metabolism. Diabetes 50 2472-2480.

Shimabukuro M, Koyama K, Lee Y \& Unger RH 1997 Leptin- or troglitazone-induced lipopenia protects islets from interleukin $1 \beta$ cytotoxicity. Journal of Clinical Investigation 100 1750-1754.

Shimabukuro M, Zhou YT, Lee Y \& Unger RH 1997 Induction of uncoupling protein-2 mRNA by troglitazone in the pancreatic islets of Zücker diabetic fatty rats. Biochemical Biophysical Research Communications 237 359-361.

Skulachev VP 1998 Uncoupling: new approaches to an old problem of bioenergetics. Biochimica et Biophysica Acta 1363 100-124.

Song DK, Park WK, Bae JH, Park MK, Kim SJ, Ho WK \& Earm YE 1997 Reduced dihydroxyacetone sensitivity and normal sensitivity to glyceraldehyde and oxidizing agent of ATP-sensitive $\mathrm{K}^{+}$channels of pancreatic $\beta$-cells in NIDDM rats. Journal of Korean Medical Science 12 286-292.

Wang H, Antinozzi PA, Hagenfeldt KA, Maechler P \& Wollheim CB 2000 Molecular targets of a human HNF1 $\alpha$ mutation responsible for pancreatic $\beta$-cell dysfunction. European Molecular Biology Organization Journal 19 4257-4264.

Weber M, Deng S, Kucher T, Shaked A, Ketchum RJ \& Brayman KL 1997 Adenoviral transfection of isolated pancreatic islets: a study of programmed cell death (apoptosis) and islet function. Journal of Surgical Research 69 23-32.

Yajima K, Hirose H, Fujita H, Seto Y, Ukeda K, Miyashita K, Kawai T, Yamamoto Y, Ogawa T, Yamada T \& Saruta T 2003 Combination therapy with PPAR $\gamma$ and PPAR $\alpha$ agonists increases glucose-stimulated insulin secretion in $\mathrm{db} / \mathrm{db}$ mice. American Journal of Physiology - Endocrinology and Metabolism 284 E966-E971.

Yalow RS \& Berson SA 1960 Plasma insulin concentrations in nondiabetic and early diabetic subjects. Determinations by a new sensitive immuno-assay technique. Diabetes 9 254-260.

Yang C, Chang TJ, Chang JC, Liu MW, Tai TY, Hsu WH \& Chuang LM 2001 Rosiglitazone (BRL 49653) enhances insulin secretory response via phosphatidylinositol 3-kinase pathway. Diabetes 50 2598-2602.

Yoon JC, Xu G, Deeney JT, Yang SN, Rhee J, Puigserver P, Levens AR, Yang R, Zhang CY, Lowell BB, Berggren PO, Newgard CB, Bonner-Weir S, Weir G \& Spiegelman BM 2003 Suppression of $\beta$-cell energy metabolism and insulin release by PGC-1 $\alpha$. Developmental Cell 5 73-83.

Zhang CY, Baffy G, Perret P, Krauss S, Peroni O, Grujic D, Hagen T, Vidal-Puig AJ, Boss O, Kim YB, Zheng XX, Wheeler MB, Shulman GI, Chan CB \& Lowell BB 2001 Uncoupling protein-2 negatively regulates insulin secretion and is a major link between obesity, $\beta$-cell dysfunction, and type 2 diabetes. Cell 105 745-755.

Zhou YP, Marlen K, Palma JF, Schweitzer A, Reilly L, Gregoire FM, Xu GG, Blume JE \& Johnson JD 2003 Overexpression of repressive cAMP response element modulators in high glucose and fatty acid-treated rat islets. A common mechanism for glucose toxicity and lipotoxicity? Journal of Biological Chemistry 278 51316-51323.

Received in final form 25 June 2004

Accepted 30 June 2004

Made available online as an

Accepted Preprint 12 July 2004 